\title{
THE COMPETENCE HEAD OF JUNIOR HIGH SCHOOL NATIONAL STANDARD PONDOK PESANTREN BASED
}

\author{
Muhammad Ubaidillah \\ Universitas Negeri Malang \\ Email: Ubaidillahmuhammad01@gmail.com
}

\begin{abstract}
The Junior High School National Standard has been programmed by the government continuously as an effort to adjust the demands of the times, and able to meet the quality requirements of graduates which in turn is an improvement on the quality of human resources. Including boarding school education based on non-formal, informal, and formal education with various advantages. The superiority of Junior High School National Standard based on the boarding school in boarding school Darus Sholah Jember lies in the system and educational value. This educational level is prepared to produce graduates who possess the noble knowledge, skills and noble character and spiritual emotions.
\end{abstract}

Keywords: Principal Competence, Pondok Pesantren

\section{INTRODUCTION}

The declaration of compulsory education of nine years of basic education is a noble step taken by the government since 1994 to realize the provisions of the Law on the task of the government to ensure every citizen earn rights to get education services, equal distribution of educational opportunities and set obligations for every citizen to travel basic education minimum for nine years. According to Mulyasa (2007), the implementation of compulsory education means that the opportunity to obtain or cultivate education for all children of the nation is considered important and relevant to answer the nation's problems as the development of human resources quality, basic needs and serious threats to the nation's power ability due to the low level of education.

The practical implication of this is the implementation of secondary education, especially the junior high school level or equivalent is intended to provide basic skills to students in developing life as a person, community members, citizens so that more ready to follow further education. The severe challenges in the implementation of secondary education is the issue of educational autonomy that the central government is pushing for the local government, demanding effective implementation of secondary education, recognizing the potentials, the availability of supporting facilities can lead to the achievement of edu- cational goals and applying the basic principles of management in favor of the human element.

School success is largely determined by teachers and principals, although teacher success is also influenced by many factors. One factor that plays an important role is the role played by the principal through leadership by building and maintaining a positive morale. In other words, the principal is required to exercise leadership that is capable of creating high spirits. The high spirit of teachers is certainly intended to support the realization of the goals of the school organization. Leadership is not a set of competencies created by a person, but an approach or work with people in an organization to accomplish joint tasks and shared responsibilities. The ability to understand this condition for the principal is very important, namely the ability to see sharply what can be done on various educational issues that arise in the field.

According Sagala (2009) about the principal cannot be separated from the leadership style, the interaction of leaders and people who led, the goals to be achieved, work situation and organizational situation, a group of people in the organization, and the environment of the organization. The leader designs the work along with the mechanism, supported by the staffs that perform the task according to the ability and expertise. Leaders use influence because of authority or power in moving social systems to 
achieve social goals, so leadership as a process of creating vision and mission influences attitudes, behaviors, opinions, values, and norms and so on from followers.

According to Tilaar (2004) The demand for competence in the world of education today is in line with the current era of openness, competence arises when showing characteristics, a) having special skills, 2) representing a vocation, c) having universal standard theories, d) devote himself to the community and exercise for himself, e) have diagnostic skills and applicative competencies, f) have autonomy in carrying out his work, g) have a code of ethics, h) have clear clients, i) have clear organization and experienced continuous development.

Principal competence is certainly reflected in the attitude and behavior as a personal figure that should be complied with and imitated, be a role model, in the implementation of leadership tasks based on expertise in managerial skills, management skills, responsibility, loyalties, and sense of equality, cultivate and togetherness among educators. Depdiknas (2009) that in the provisions of the applicable regulations, especially in Government Regulation Number 19 The year 2005 on National Education Standards (SNP), then in the future every school at all levels, including Junior High School, must meet the SNP. One effort to achieve the SNP as determined, then each school is required to make School Development Plan (RPS).

The Junior High School group that meets SSN criteria is prepared and nurtured to become self-sustainable SSNs, and therefore is given a fishing fund grant to develop eight aspects of the National Education Standards. In addition to educational facilities should receive special attention, then other aspects of education also need to be considered, namely aspects of graduate, PBM, HR, management, budgeting, and assessment standards in the implementation of SSN pilot national standard.

According to Tilaar (2006), the standardization of national education is a need and demand, both political demands, demands of globalization, and the demands of a progress. These standards are not rigid or absolute, but standards are constantly increasing. For this reason, boarding school as a place of Islamic religious education is very possible to give special value to religion to junior high school, at least in order to practice the implementation of formal education and, including junior high school can stand in line with government-owned Public Junior High School.

The development of educational institutions in Islamic boarding schools known as the implementation of Islamic education has long existed in Indonesia, even in practice implementation has been accompanied by modernization self-boarding school by entering general lessons in the curriculum that is held, or known as a modern boarding school that organizes public schools such as elementary, Junior high, high school, vocational school and even college in the environment of Pesantren culture.

The number of scholars or leaders of boarding schools that provide formal, education has spawned a new phenomenon in the practice of religious-based education, and this can be interpreted as the era of the rise and new spirit of Indonesian society, especially Muslims who aspire to the establishment of the institution of general formal education based religion in boarding school. The emergences of pesantrenbased education with the school system or madrasah get a pretty good response, even seen as a partner of the government in an effort to educate the nation's life.

According to Arifin (2010) in the context of national education, pesantren is a sub-system of non-formal education, this is because since the growth of pesantren more emphasized the teaching of religion in the form of classical Islamic books as an effort to continue the main purpose of pesantren educate candidate ulama, and also understand Islam tradition. As we know, pesantren is very strong with the practice of education that emphasizes religious education as his trademark. The peculiarities of existing educational institutions in boarding schools when viewed from the implementation system has certain characteristics that are, 1) Kyai as a figure or central leader, 2) boarding school as a place of students, and 3 ) the existence of education or teaching of Islam (Dhofier:1984)

It is said pesantren-based because of the existence of general formal education National Standards Junior High School existing pesantren environment boarding course will grow and 
develop by influenced by culture, religious values, and excellence-based Islamic education, where the role of kyai or cottage leadership as a central figure is very coloring on the organization of education in it. The excellence of the National Junior High School based on boarding schools lies in the system and the value of education. In East Java Province, there are many boarding schools that provide non-formal, informal and formal education, including formal junior high school education based on Islamic boarding school by promoting Islamic values in daily life.

Especially for National Standards Junior High School located in the boarding school environment is very limited number, lack of number of National Junior Standard existing in the boarding school environment is a special attraction to be studied and researched more deeply. Such attractiveness is a sign of the principal's success in leading and managing that is supported by the foundation's board, teachers, administrative or administrative staff, school committees and stakeholders and other members of the school community.

\section{METHOD}

This research uses the qualitative approach. A qualitative approach is chosen in view of this study in the form of an action or activity of a person or persons concerned with the process of formulating educational policy decisions, and the object of research is natural. The data revealed in the form of words, sentences, documents, and not a number. In accordance with the focus of research is the competence of Junior High School Principal Standards Based on Pondok Pesantren, and research objectives that generally want to describe the competence of the principal, the implementation of management by the principal in the Junior High School National Standard, and implementation Junior High School program National Standard. With regard to it, the research in Darus Sholeh Jember District Junior High School.

According to Bogdan \& Biklen (1998), qualitative research emphasizes on processes and meanings that are not tested or measured precisely in terms of quantity, amount of intensity or frequency. Bogdan \& Taylor (1993) states that the qualitative approach is a research procedure that produces descriptive, qualitative data, in the form of speech or writing and the desired behavior of the person (subject) it.

With regard to the explanation, this study used case study research design, in-depth observation, interviews, and documentation study. Qualitative data analysis is done interactively and continuously at every stage of research, so that until complete and until saturated. Testing data credibility is done with the extension of observation, increasing persistence, triangulation, peer examination, member check.

\section{RESULT}

\section{Leadership Competence of Junior High School National Standard based on Pondok Pesantren}

The leadership competency of the principal is defined as the ability of the principal in his position as a person in carrying out his or her role to lead or head the school. As principal leaders develop attitudes and behaviors that will color the organization's climate and social life in the school environment. Such attitudes and behaviors can tend to be democratic, authoritarian or familial. His position as a leader, principal as the highest position in the school, and the environment of the hut there is a foundation that became his boss. With these positions, the leadership developed has a special character, compared to leadership in public schools that are not located within the boarding school environment.

Head of Junior high school National Standard Darus Sholeh Jember has an adequate education quality, with the latest education in Master of Education (S2). In addition, which is he is also status as Civil Servants (PNS) are united in Junior High School Darus Sholah Jember Regency. With the level of education and employment status, the competence of the headmaster of Junior High School Darus Sholah Jember Regency is undoubtedly the quality. The transparency of the principal has run it professionally as a leader. School programs are planned together and delivered openly to all parties at the school.

Nevertheless, from the results of research in the field, it is evident that the principal Darus Sholeh Jember District in his leadership tends to apply the authoritarian style. This is 
possible, because with the level of education and employment status, as well as being the principal of the qualification selection conducted by the government, concerned becomes superior among teachers, staff and even among the boarding school residents. Despite applying an authoritarian style of leadership, the principal compensated by paying sympathetic attention to his subordinates.

\section{The Competence of Junior High School National Standard based on Pondok Pesantren in Implementation of Management}

Principal competence in the implementation of management (planning, organizing, mobilization, and supervision) in managing the school he leads professionally. In addition, it will also describe the independence of the principal to make decisions and determine policies related to school management, in organizational relationships with foundation managers or boarding schools.

\section{Planning}

Implementation in the implementation of the planning function, the competence head of Darus Sholeh Jember Junior High School has the background of master education, civil servant status and has passed the selection as principal through PTSP program. Thus, its existence, concerned in general can be said to be more systematic in planning. In addition, the planning developed is not too influenced by the foundation. In addition, in planning the headmaster of Darus Sholah Junior High School also involves the existing human resources, to get input and obtain support for the planning made. Another thing that can be observed planning is the independence of schools in composing from the intervention of the foundation. In the position as a school under the organization of Pondok Pesantren, it is something that is rarely encountered.

In most schools located within Pondok Pesantren, the dominant foundation as owner and manager of Pondok Pesantren is usually dominant. Associated with the function of the implementation of the planning function by the head of Darus Sholah Jember District Junior High
School National Standard is the understanding concerned in the steps of preparation of planning and ability to arrange it. This is evident from the School Development Plan (RKS) document for four years, and the School Budget and Expenditure Plan (RAPBS) for three years. The preparation is done solely by the principal and then clashed with the elements of the school, to get input and perfection.

\section{Organizing}

The organizing function is evident from the steps of establishing a working group on any program or activity developed and implemented by the school, including the working group for submission to SSN implementation. The established working group also involves various elements of the school, teachers' boards, administrative staff, school committees, and programs involving pupils.

Judging from the organizational structure developed by the head of Darus Sholah Jember District Junior High School National Standard, it appears that an organizational relationship among the elements of the organization is clearly the structure. The principal as a leader is the chair of the foundation and is consultative in consultation with the Office of Education and School Committees. Under the headmaster, there is a deputy headmaster, and at the next level, there is a school treasurer and administrative staff, followed by teachers in charge of curriculum, facilities, students, and public relations. Then the bottom level is the homeroom teacher and Counseling Guidance Counseling (BK) who deal directly with students.

When viewed from the organizational structure emblazoned on the walls of the principal's room and the teacher's room, it appears that there is clarity in the delegation of authority and duties of the principal to the organizational elements under it, as well as the flow of responsibility. With the education level and civil service status as civil servants, head of Darus Sholah Jember District Junior High School National Standard tends to develop authoritarian leadership and ignores the flow of delegation of authority, responsibility, and reporting according to the levels within the organizational structure. 


\section{Movement}

The formation of working groups in every school program implementation is a test of the ability of the head of Darus Sholah Jember District Junior High School National Standard to implement the mobilization function in managing the school. As is known between the functions of organization and movement has a close relationship. Quality in the application of organizing function will determine the quality in the application of the movement function. With the level of education and employment status and the trust of subordinates to the ability of the principal, fostering adherence among teachers and administrative staff to carry out the tasks assigned to them.

This is reinforcing by the flexibility provided by the foundation to the principal to take action in the form of punishment penalty if there are teachers or administrative staffs are negligent or undisciplined in carrying out the task. The headmaster is personally capable of implementing the mobilization function in effective school management, although it is possible to carry out the tasks run by his subordinates rather than being based on the volunteers, but rather to compulsion, because of the respect and fear of the principal, who tend to be authoritarian and reluctant -suits applying sanctions to subordinates who do not perform the task well.

\section{Monitoring}

Associated with the implementation of the movement function is strongly influenced by the existence and trust of subordinates to the ability of the principal, in the application of the function Supervising, head of Darus Sholah Jember District Junior High School National Standard can be said no difficulty to do that task. Obedience and a tendency to fear the headmaster who is present among teachers and administrative staff tends to relieve the principal's duties to implement supervision.

The supervisory function developed by the principal Darus Sholah is direct in the working groups established to execute school programs that utilize various organs within the organizational structure. Supervision also tends to be accomplished through checking the results achieved by the working group in the implementation of programs developed by the principal. Oversight of the process or implementation of the program is not effectively implemented. This happens because of the principal's self-confidence that the working group set up to run the school program will be well implemented so that supervision is sufficient to achieve results.

Related to the supervision of the positive value applied by the head of Darus Sholah Jember District Junior High School National Standard is the openness in school management, especially in financial management. Openness instituted by the principal will provide a positive climate for the effective implementation of oversight functions. Openness is also an effective process of monitoring between the components of the school and among teachers and administrative staff in the implementation of tasks and implementation of school programs proclaimed by the principal.

\section{Principal Competence of Junior High School National Standard based on Pondok Pesantren in School Program Implementation}

Implementation of national standard school programs in boarding schools has a great influence to achieve success in the implementation of school programs. As a school with SSN status, programs implemented by the principal, should be in accordance with the standards set by the government. The standards include eight kinds: graduate competency standards, content standards, process standards, quality standards of educators and education personnel, infrastructure standards, management standards, educationfinancing standards and education assessment standards.

The principal in the implementation of the junior high school program Darus Sholah in sequence will be described starting from, first, the implementation of the vision of the mission of pesantren-based schools. Characteristic of modern pesantren that developed and much in demand by people who have formal education institutions that display knowledge of religion and general knowledge in an integrated environment called pesantren. Second, improving the quality of teachers based on pesantren. Darus Sholah Junior High School National Standard as the 
holder of good and bad control of schools is very coloring improvement of teacher quality. The steps taken in cooperation with universities in teacher improvement, the breakthrough is taken because the insight and education of the principal is better than the teachers who exist in the school environment.

Third, the improvement of teaching-based learning facilities of pesantren. The school facilities in Darus Sholah Junior High School National Standard have been sufficient, the students' development trend is relatively stable, and the acceptance of new students is done by the selection to match the needs of the students / students to the infrastructure available in the boarding school. Efforts by the principal to balance the existing means by making policies to accept students with the first applicant indent system. Thus, the students who have registered first are a priority to be accepted. Fourth, the school financing program is based on pesantren. School Operational Assistance (BOS), and the assistance of santri guardians are usually accepted every year lessons become the backbone of school financing. Parties to boarding school less much help the operational needs of schools, especially Darus Sholah Junior High School National Standard because it is considered well established in terms of school financial management.

Fifth, improving the quality of pesantrenbased learning. Learning has been going well, moreover since the establishment of this school SSN status. Policies taken related to improving the quality of teachers by integrating school curriculum with the curriculum in boarding schools. For the achievement of school goals and the purpose of the pesantren, the principal improves the quality of teachers through workshops or training by utilizing the existing universities in Jember. Sixth, the development of cooperation with outsiders based on pesantren.

The pattern of head Darus Sholah Junior High School is relatively more advanced, at least seen from the steps of the principal to cooperate with outsiders who can advance the school, and at the same time can advance the boarding school. Seventh, the program of pesantren-based student activities. Student activity is done well; in preparing program headmaster to get it first before student activity executed. Preparation of student activities program conducted together intended to have a contribution of the mind of the citizens of the school. Starting from the board of teachers, administrative staff and from the school committee. The head of the pesantren who is also the chairperson of the foundation does not have too much interference in the affairs of education. All school programs, including student activity programs, are fully submitted to the principal.

\section{DISCUSSION}

\section{The Leadership Competency Head of Junior High School National Standard based on boarding school}

Good schools need school leaders with responsibilities and work together with teachers as well as with other school components professionally as well. Some of the steps that the principal can take in managing an educational organization are 1) the principal is more responsive to the needs of stakeholders and the community to determine the quality of education, 2) the principal must be able to determine the relevant model for the existing resource, 3 ) the subordinate obtain the incentive appropriate to maximize resource efficiency (Bush \& Coleman, 2008)

According to Charles (2009) the leadership of educational organizations also offers a model of school self-management that is also used by various countries with broad autonomy to educational institutions to improve effectiveness through the flexibility of utilizing existing resources, improving quality, increasing school pruning and stakeholders, improving financial capacity, the school is thoroughly appropriate for the priority fit with student data and their needs.

Head of Darus Sholah Jember Junior High School National Standard able to execute the task professionally, for example in cooperation with various related parties in developing and improving quality of education in school especially relation with the school committee, so what becomes school program can be communicated well from planning process for monitoring. The competence of the principal of Darus Sholah Junior High School National Standard reflects the attitude and behavior as a personal figure that should be obeyed and imitated, to be the role model, in carrying out leadership task based on 
skill in managerial ability, management ability, responsibility, loyalty, and togetherness among fellow educators.

According to Arifin (2007) the competence of the principal has the following characteristics: 1) to have adequate, competent and qualified qualifications, 2) to lead effectively and carry out the vision, mission to foster and promote the school community; 3 ) improving the quality of schooling, 4) managing resources and materials wisely, 5) able to work with teacher and students, 6) able to work with parents, school council, community, and other related bodies, 7) improving the morale of school staff, 8) sustainable and selfdevelopment.

Principals also always involve all the elements that exist in the school in the preparation and implementation of school programs. According to Wahjosumidjo (2008) explains that the success of the principal is determined by his ability to utilize school resources to achieve the objectives in accordance with the situation, the skills, personality, basic skills, experience, and skills as well as administrative and supervisory competence are required.

The principal's task according to Mulyasa (2007) principal is responsible for the implementation of school activities, school administration, educational staff development and utilization and maintenance of infrastructure facilities. The principal is fully responsible for the school's microeducation management that takes place in relation to school learning, cultural climate and the quality of education. The principal, as well as the manager who has executive and leadership functions, needs to know also his internal capabilities in responding to the needs of his environment by prioritizing the assumptions as an educational leader who understands the perspectives in formulating educational programs, educational objectives and the issues involved.

As described above, the function Head of Darus Sholah Junior High School National Standard becomes more dynamic and open to respond to various developments that occur both in school and in society as well as various problems that appear in the internal school especially problem relation individual teachers, employees, and principals. According to Wahyudi (1995) argued that quality human resources are characterized by the ability to work professionally with the ori- entation of quality and excellence and ability to work from a dynamic reality, able to find alternative ways to solve problems and develop research patterns. With the ability of the individuals above that guarantee that professionalism will grow and develop. Form the leadership of the principal as an effort to make the most of the resources available to manage, control the led institution. Therefore, it needs qualified human resources, such as agile, visionary, and credible leadership in taking policy and moving school organization.

Most people consider effective leadership to be active, not passive, consistent rather than inconsistent, more concerned with principles than non-principles or trivia, powerful than weak, and communicative rather than fussy. Thus, the leadership of the principal as a process of learning leaders creates a vision of education, its implementation by influencing attitudes, behaviors, opinions, values, norms and so on from teachers and other educational professions in schools to reevaluate vision. The principal's competence is implicitly acknowledged that the principal has led the school professionally; the principal has also involved all the components of the school each will do something, ranging from teachers and staff to talk and coordination, always open and transparent, including financial issues.

The principal always invites the committee members to ask for input and suggestions in developing the school. Head of Darus Sholah Jember Junior High School National Standard is a highly educated person (S2) and is a civil servant so that it can be considered professional and headmaster has passed the competency test of the candidate principal. The visionary leadership of the headmaster is exposed to his ability to organize the future and strives to achieve that future by managing instructional tasks, and interacting with other leaders in this professional interaction (Sagala, 2009)

Principal leadership competence is the demand of every leader of the institution carried. According to Wahjusumidjo (2008) argued that the principal as a leader should be in daily practice always try to pay attention and practice leadership function in School life. Head of Darus Sholah Jember Junior High School National Standard is also able to read the needs of the existing community, so that the program is also in accordance with the needs, and the 
implementation is right with the planned, the principal can perform his duties properly or professionally, as able to respond to foundation and committee well, the principal can also integrate the pesantren culture with religious activities, and the school committee program through the planned program of the school, certainly with the hope of graduating students who are IMTAQ AND science and technology. With the mastery of IMTAQ AND IPTEK, this means there are two things that can be dedicated to the public that is about religious knowledge and general knowledge and technology.

Success in carrying out its role cannot be separated from the principal foresight in reading the condition and situation and accommodate the suggestions from various parties at the school's most proposed teachers, TU and school committee. In addition, efforts to improve the quality of teachers and education in the school environment is the main goal of the principal by emphasizing discipline in every task, and also utilize boarding school even though not dominant, with a qualified teacher will produce quality graduates. Head of Darus Sholah Jember Junior High School National Standard is a person who humorist and have a very high social sense, on the sidelines of busy school principals take the time to control and supervise teachers and other staff.

\section{Leadership Competence Junior High School Principal National Standard based Boarding School in the Implementation of Management}

According to Santoso (2008) said as a manager, the principal must develop the following skills: 1) objectivity towards human relations and behavior, 2) able to communicate, 3) authority, 4) self-awareness, 5) teaching. Meanwhile, according to Wajosumidjo (2008) a manager in the organization has the functions: 1) working with and through others, 2) responsible and accountable, 3) with limited time and resources able to deal with problems, 4) thinking realistically and conceptual; 5) as a mediator, 6) as a politician, 7) as a diplomat, 8) difficult decision makers.

Head of Darus Sholah Jember Junior High School National Standard performs its duties and functions in a simple and tactical way, as tactical work is seen and appreciated rather than conducting discussions and meetings. Principals acting and working, including in planning and implementing the program always apply the principles of management. The principal has what size to do and may be done for the development of the school as well as how to control and evaluate it.

In order for the principal actively and efficiently to execute its function as the manager, the principal must understand and be able to realize technical skills, human skills, and conceptual skills in the actions and behaviors of organizational values. Head of Darus Sholah Jember Junior High School National Standard involves the teachers and school committees for planning and managing the program activities and the continuity of this school going forward. The principal assumes that this school belongs to all, so that all of them feel the need to be involved in the development of the school including in terms of management in accordance with their respective portions and responsibilities.

Involvement of school components in accordance with their respective responsibilities, making it easier for schools and foundations in implementing programs and supervision. Ease gained at least felt by the foundation, for example if you want to know how far the development of school management, including the progress achieved. The management model that the principal runs is very easy to evaluate, by looking at how the school's physical development plan, whether the principal involves the committee or not, and how to plan and implement the KBM.

According to Wahjosumidjo (2008) with the base of the management functions, as the foundation of the leadership of the principal will be born the pattern of piker, attitude, and behavior of the principal is effective and will realize the effective school. The principal also does not hesitate to provide direct direction how appropriate steps for TU staff in providing services to students and teachers for the development of education and KBM in the school environment, and sometimes interspersed with jokes but what is done by Head of Darus Sholah Jember Junior High School National Standard very helpful in performing the task effectively and efficiently.

According to Danim (2009) said that skills are commensurate with the word skill, and skill 
called skills. Whereas, managerial is an adjective related to leadership and management. In many libraries, the word managerial is often referred to as the origin of the word from management which means to train the horse or literally interpreted as to handle which means taking care, handling, or controlling. While management is a noun that can mean management, governance or management.

In principle management understanding has several characteristics as follows: 1) there is a goal to be achieved, 2) as a combination of science and art, 3) is a systematic, coordinated, cooperative, and integrated process in utilizing its elements, 4) there are two people or more cooperating within an organization, 5) based on the division of labor, duties and responsibilities, 6) includes several functions, 7) is a means to an end. In the implementation of management, the Head of Darus Sholah Jember Junior High School National Standard, for example in making RAPBS always get support from the committee and the foundation. Foundations and committees also help if there is a lack of funds and control the implementation of RAPBS. This condition then encourages the principal to involve committees, teachers and staff to engage intact according to their foreign responsibilities.

In making the RAPBS SSN the principal submits to the SSN teamwork whose members are complete enough to have teachers, TU staff, and the student guardian element or school committee. Head of Darus Sholah Jember Junior High School National Standard delegated the administration and prepared things related to the implementation of surveys and school visitation to TU staff. The task given by this principal to welcome the SSN program that will be accepted Junior High School this. Each activity, especially coordination meetings, is always on the record, it shows that the head of the school has fully involved the relevant parties in accordance with their respective duties.

The school committee is given a portion to assist school management, especially its supervision, although in the planning is also involved indirectly, it is expected that there are things that are not involved indirectly, it is expected if there are things that are less appropriate can be known to be found an exit. According to Kontz (1984), management capabilities include technical skills, human skills, and conceptual skills. Technical ability is the ability that is closely related to the use of tools, procedures, methods, and techniques in a management activity correctly.

The ability of human relations is the ability to create and nurture relationships, understand and encourage others so that they work voluntarily, non-coercion ally and more productively (working with people). According to Rivai (2009) at the most operational level, school leaders are people at the forefront who coordinate efforts to improve quality learning. This role is clearly done by Head of Darus Sholah Junior High School National Standard. In his daily life in carrying out the duties and function of the principal, more prioritize to the quality of education, the quality of learning by teachers, to produce qualified graduates.

The teachers are always given a briefing in the form of training and workshop teacher, both organized by boarding schools and state universities. To achieve this implementation, the principal does coordination with various parties. Organizing, especially in the distribution of tasks to the team appointed to improve the quality of learning, the principal has performed its functions properly. For example, to meet and coordinate with the SSN monitoring team of the Directorate of Development of Junior High School, the principal delegates to the school SSN team, while in coordination and in accordance with its assigned tasks and functions. This is done to develop a spirit of openness within the team and also to avoid a monopoly of responsibility in a team. The division of work that the principal plans to accomplish by members of the occupational group, determining the relationships between them and the proper employment.

\section{The Leadership Competence Head of Junior High School National Standard based on boarding school in the implementation of the National Standard Junior High School program}

According to Bush and Coleman (2008), interpreting strategy is a long-term process (three to five years) that translates vision and mission into significant, measurable, and practical outcomes. Although this is a process that requires two-way communication in all stages should be focused on the main objectives and practical credentials of schools or colleges. Implementation of the 
school program environments Darus Sholah Junior High School National Standard run well, ranging from $\mathrm{KBM}$, students, and activities involving outsiders, this is not independent of the seriousness of schools in implementing programs that have been planned previously.

The involvement of various parties related to each program becomes the key to the success of the existing program. Head of Darus Sholah Junior High School National Standard often asks for input to the school's foundations and committees on how to properly speak with the guardian and outsiders so that they support the programs that have been prepared, especially those related to the funds, and often we invite the foundation and school committees work together to approach the guardians and outside parties so that the school gets trust and it is easy to get grants from the guardians and outsiders for example to build a classroom.

A continuous process of engaging in arrangements related to the preparation, purpose of making, financing and evaluation in a way that is capable of reaching all levels of the organization, involving people within the organization in accordance with its capacity and responsibility for implementing plans in their own best interests, and provide an annual planning, budgeting, and evaluation framework. The foundation also knows if the current principal is able to run the program well, especially related to graduation. Exceptional year graduation, in addition to passing all, the value obtained by students and satisfactory, this shows if the planning and cohesiveness in the implementation of the program happening well, so the results boast of schools and communities, especially foundations and school committees.

The National Standard School (SSN) is a school that has complied with the National Education Standards (SNP) stipulated by the SK stipulation as for the National Standard School (SSN) by the Directorate of Development of Junior High School of the Ministry of National Education. Related to that Article 35 of Law Number 20 of 2003 on the National Education System mandates that the National Education Standards are used as the foundation and guideline for the development of educational units. Minimum criteria on the various aspects relevant to the implementation of the national education system that must be met by the providers of educational units, applicable throughout the jurisdiction of the Unitary State of the Republic of Indonesia. The SNP includes competency standards for graduates, educational content and education personnel, infrastructure facilities, educational processes, financing management processes, and appraisals.

Head of Darus Sholah Junior High School National Standard also emphasizes and optimize the program that is closely related to the formation of personality based on religious values in pesantren, because of the pesantren identic with students or learners who "berakhlakul karimah", so that existing pesantren culture can be taken home when graduated from school. The program of improving the quality of morality of students is also a point of emphasis focused by the foundation to the school especially the principal, the foundation called attention special attention the school in educating students about morals, academic achievement. School organizations are like small communities that have different characteristics with people outside of school. The school community consists of several components, both small and large, they are interdependent and work together to achieve the predetermined educational objectives of forming a whole human, faithful and devoted, noble, healthy, knowledgeable, capable, creative, independent, and become citizens A democratic, responsible country.

The wishes and hopes of the founder of the pesantren are poured by the Head of Darus Sholah Junior High School National Standard through the vision of his school mission, such as establishing students about religion for the benefit of the world and the hereafter, as well as many other missions deprogrammed by Head of Darus Sholah Junior High School National Standard through this SSN. In the SSN guidelines mentioned that the National Standard School is one of the quality improvement programs. In addition, the National Standard School (SSN) is a national program, so that all parties participate, in accordance with their fields. Therefore the function or role of all parties as well as for each party from the school level to the level of Directorate of Junior Development. 


\section{CONCLUSION}

Competence in carrying out the role and function as principal can be shown well for example headmaster capable of responding to various developments that happened both at school and also in society and various problems that appear in the internal school especially problem of individual relation teacher, the employee also executed well. The leadership style used is authoritarian, although the principal authoritarians emphasize more cooperation with teachers and other employees that make the principal so influential in carrying out his leadership professionally. In the implementation of management, the Head of Darus Sholah Junior High School National Standard also showed his competence in implementing the program that has been made. The National Standard School based on boarding schools requires the competence of a principal figure to achieve the objectives of the SSN itself. In addition, the advantages of this SSN implementation is how competently headmaster with teachers and other school residents continue to run the vision and mission of pesantren-based schools.

\section{REFERENCE}

Arifin, I. 2007. Tantangan dan strategi dalam Menggagas Sekolah Unggul Masa Depan. Jurnal Tenaga Kependidikan, 2 (2): 31-43.

Arifin, I. 2010. Kepemimpinan Kyai dalam Perubahan Manajemen Pondok Pesantren: Kasus Ponpes Tebuireng. Pustaka Pelajar.

Bogdan, R,. \& \& Taylor, S.J (193). Kualitatif Dasar-Dasar Penelitian. Penerjemah: A. Khozin Afandi. Surabaya: Usane Offset Printing.

Bogdan, R.C, \& Biklen, S.K.B. 1998. Qualitative Research for Education: An Introduction to Theory and Methods. Boston. Allyn and Bacon, Inc.
Bush, T \& Coleman, M. 2008. Manajemen Strategis Kepemimpinan Pendidikan. Jakarta: IrCISoD.

Carles W. 2009. Guru Progesional: Penyiapan dan Pembimbingan Praktisi Pemikir. Bandung: Alfabeta.

Dhofier, Z. 1984. Tradisi Pesantren: Studi tentang Pandangan Hidup Kyai. Jakarta. LP3ES.

Depdiknas (2009). Panduan Pelaksanaan Sekolah Standar Nasional. Jakarta.

Danim, S. \& Suparno. 2009. Manajemen dan Kepemimpinan Transformasional Kepala Sekolah: Visi dan Strategi Sukses Era Teknologi, Situasi Krisis dan Internasionalisasi Pendidikan. Jakarta: Rineka Cipta.

Kontz, H. 1984. Management. London: McRow Hill International Student Book Company.

Mulyasa, E. 2007. Menjadi Kepala Sekolah Profesional. Bandung: Remaja Rosdakarya.

Rivai, V. 2009. Kepemimpinan dan perilaku Organisasi. Bandung: Raja grafindo Persada.

Sagala, S. 2009. Kemampuan Profesional Guru dan tenaga Kependidikan. Bandung. Alfabeta.

Santoso, D. 2008. Teori-Teori Kepemimpinan. Surakarta: LPP UNS dan UNS Prees. 2000.

Tilaar, H.A.R. 2004. Paradigma Baru Pendidikan Nasional. Jakarta: Rineka Cipta.

Tilaar, H.A. R. 2006. Paradigma Baru Pendidikan Nasional. Jakarta: Rineka.

Wahjosumidjo. 2008. Kepemimpinan Kepala Sekolah: Tinjauan Teoritik dan Permasalahannya. Jakarta. Rajagrafindo. Alfabeta.

Wahyudi. 2009. Kepemimpinan Kepala Sekolah dalam Organisasi Pembelajar. Bandung. Alfabeta. 